\title{
Adolescent Social Skills, Perception of Social Support and Motivation to Learn: the impact on School Performance
}

\author{
Humberto Claudio Passeri Medeiros ${ }^{1}$ \\ Adriana Benevides Soares ${ }^{1,2}$ \\ Marcia Cristina Monteiro ${ }^{3}$ \\ ${ }^{1}$ Universidade Salgado de Oliveira, Niterói, Brasil \\ ${ }^{2}$ Universidade do Estado do Rio de Janeiro, Rio de Janeiro, Brasil \\ ${ }^{3}$ Universidade Brasil - UNIESP, Duque de Caxias, Brasil
}

\begin{abstract}
The aim of this study was to verify whether the School Performance variable can be explained by the Adolescent Social Skills (ASS), Motivation to Learn and Perception of Social Support constructs in groups of students that were with and without an age/grade discrepancy in Elementary School and in Acceleration classes. This study also aimed to compare the constructs in the groups. Participants were 500 students from public schools, aged 15 to 18 years, divided into two groups according to the school progression. The Social Skills Inventory for Adolescents, the Learning Motivation in Elementary Education Scale, the Social Support Appraisals Scale and the Class Council Maps of the participating institutions were used. For the data analysis, Multiple Linear Regression was performed and Student's $t$-test. The results showed that Adolescent Social Skills, Motivation to Learn and the Perception of Social Support better explained the school performance of the regular progression students. When comparing the groups, the regular progression students presented higher mean scores in Empathy, Self-Control, Civility, Assertiveness, Social Development and in the overall total of the ASS scale. The same occurred when comparing the means of Perception of Social Support and Motivation to Learn of students with and without age/grade discrepancy. The data obtained can contribute to preventive intervention actions for academic competences and social skills, aiming at improving school performance and maintaining regular progression.
\end{abstract}

Keywords: Adolescent Social Skills; social support appraisal; motivation to learn; School Achievement.

Habilidades Sociais, Percepção de Apoio Social e Motivação para Aprender: o impacto no Rendimento Escolar Resumo

O objetivo desse estudo foi verificar se a variável Rendimento Escolar pode ser explicada pelos construtos Habilidades Sociais de Adolescentes (HSA), Motivação para Aprender e Percepção de Apoio Social nos grupos de alunos que estão no fluxo regular e em defasagem de idade/ano no Ensino Fundamental e em classes de Aceleração. Foi também objetivo desse estudo comparar os construtos nos grupos. Participaram 500 alunos de escolas públicas, com idades variando de 15 a 18 anos e divididos em dois grupos conforme o fluxo escolar. Utilizou-se o Inventário de Habilidades Sociais de Adolescentes, Escala de Motivação para Aprender no Ensino Fundamental, Escala de Percepção de Apoio Social e os Mapas de Conselhos de Classe das instituições participantes. Para a análise dos dados, foi realizada a Regressão Linear Múltipla e o teste $t$ de Student. Os resultados apontaram que as Habilidades Sociais de Adolescentes (HSA), a Motivação para Aprender (MA) e a Percepção de Apoio Social (PAS) explicam mais do rendimento escolar dos estudantes em fluxo regular. Na comparação entre os grupos, os alunos em fluxo regular apresentaram médias mais altas em Empatia, Autocontrole, Civilidade, Assertividade, Desenvoltura social e no total geral da escala de HSA. O mesmo ocorreu quando comparadas as médias de Percepção de Apoio Social e Motivação para Aprender de alunos com e sem distorção de idade/ano. Os dados obtidos podem contribuir com ações preventivas de intervenção para competências acadêmicas e habilidades sociais, objetivando a melhoria do rendimento escolar e a manutenção do fluxo regular. Palavras-chave: habilidades sociais de adolescentes, percepção de apoio social, motivação para aprender, rendimento escolar.

\section{Habilidades Sociales de los Adolescentes, Percepción del Apoyo Social} y Motivación para Aprender: el impacto en el rendimiento escolar

\section{Resumen}

El objetivo de este estudio fue verificar si la variable Rendimiento Escolar puede explicarse por los constructos Habilidades Sociales de los Adolescentes (HSA), Motivación para Aprender (MA) y Percepción de Apoyo Social (PAS) en grupos de estudiantes que se encuentran con y sin retraso de edad/año en la escuela primaria y en las clases de aceleración. La finalidad de este estudio también fue comparar los constructos en los grupos. Participaron 500 estudiantes de escuelas públicas, de 15 a 18 años que fueron divididos en dos grupos de acuerdo con el flujo escolar. Se utilizaron el Inventario de HSA, la MA en la Escuela Primaria, la PAS, los Mapas del Consejo de Clase de las instituciones participantes y los datos de Regresión Lineal Múltiple. Para el análisis de datos, se realizaron regresión lineal múltiple y prueba t de Student. Los resultados mostraron que HSA, MA y PAS explican más sobre el rendimiento escolar de los estudiantes en el flujo regular. Al comparar los grupos, los estudiantes en flujo regular tuvieron promedios más altos en Empatía, Autocontrol, Civilidad, Asertividad, Desarrollo Social y en el total general de la escala HSA. Lo mismo ocurrió al comparar los medios de PAS y la MA de los estudiantes con y sin distorsión de edad/año. Los datos obtenidos pueden contribuir a las acciones de intervención preventiva para las competencias académicas y habilidades sociales, con el objetivo de mejorar el rendimiento escolar y mantener el flujo regular.

Palabras clave: Habilidades Sociales de los Adolescentes; Apoyo Social; Motivación para Aprender; Rendimiento Escolar. 


\section{Introduction}

The transition from Elementary Education (EE) to High School (HS) has been outlined as critical for the student due to the characteristic challenges of this stage of formation. Innumerable variables are present and can explain possible obstacles to the progression, ranging from the number of curricular components to studying autonomously (Angelin, 2012). There is a portion of students that end up failing and increasing the age/grade discrepancy index. According to the Instituto Nacional de Estudos e Pesquisas Educacionais Anísio Teixeira (INEP - Anísio Teixeira National Institute of Educational Studies and Research, 2017), in Brazil 22.3\% of Fundamental Education students are repeating years and in the state of Rio de Janeiro these total $45.1 \%$.

Understanding the reasons that lead students to experience failure in Elementary and High School Education could be relevant for reintroducing them into the regular grade. It may be important to consider the difficulties encountered by students in the pedagogical, social and cultural fields that lead to low performance. The Lei de Diretrizes e Bases da Educação Nacional (LDBEN - National Education Guidelines and Bases Law, 1996) established possibilities for students that have a history of school failure and the consequent age/study grade discrepancy to be included in progression correction actions (Nunes, Pontes, Silva, \& Dell'Aglio, 2014). Known as the "Projeto de Aceleração" (LDB-EN - Acceleration Project), this includes a curriculum that concentrates the teaching of the main contents in less time. For this, the pedagogical approach needs to be based on the selection of central themes, such as the mastery of the four mathematical operations and their applicability, reading, writing and textual interpretation, worked on with a view that enables learning and makes it possible to overcome difficulties considering cognitive, affective and behavioral aspects.

Actions related to affective and behavioral components can make students more assertive, participatory and empathic. In this way, their social relationships and interactions can be improved and contribute to the cognitive process (Perassinoto et al., 2013). This can also lead the students to improve their social competence with gains in school performance (Fernandes, Leme, Elias, \& Soares, 2018; Wyler \& Schueda Raiser, 2014). Social competence can be understood as the ability to think, feel and act according to the objectives and demands of situations, having an evaluative effect in relation to social performance (Z. Del Prette \& Del
Prette, 2009). Elias and Marturano (2014) highlighted the empirical evidence that the academic, interpersonal and behavioral fields are interconnected. Problems presented in the period of the initial years have effects on school performance and on relationships during the formation in Elementary Education, compromising social competence.

The literature indicates that being socially competent in the school context requires an ordered set of actions by individuals based on their social skills (Angelin, 2012; Dascanio et al., 2015). Social skills are classes of behaviors that contribute, in social interaction situations, to satisfactory social performance (Pereira, Marturano, Gardinal-Pizato, \& Fontaine, 2011; Sapienza, Schoen, \& Fisberg, 2014). When these skills are poorly elaborated or absent, they can be learned in order to make the living process more harmonious (Pizato, Marturano, \& Fontaine, 2014).

In the study by Barreto, Freitas and Del Prette (2011) with the aim of characterizing and comparing the repertoire of social skills and the types of problematic behaviors (internalizing or externalizing) self-assessed and observed by the teacher, the authors had the participation of 50 students. All the participants presented behavioral and learning difficulties and were in the transition between the end of the first and the beginning of the second stages of Elementary Education (EE). The results of the study suggest that learning difficulties and behavioral adjustments can be solved with specific programs that should prioritize social behaviors, especially in the Empathy, Civility, Assertiveness and Coping subclasses, to improve students' performance. In this stage of EE there are intense changes in biopsychosocial aspects, also highlighted by Casali-Robalinho, Z. Del Prette and Del Prette (2015). A similar result was obtained in the studies carried out by Silva and Rapoport (2015) and Zambon and Rose (2012) within the same age group, showing an association between social conflicts and low school performance experienced by children or adolescents.

These studies sought to identify the factors in the interpersonal relationships, their skills and competences, which can often interfere with school performance and the perception of how the people they deal with can collaborate to solve everyday situations. The successive failures and the low level of school performance of students can be the result of their inner conflicts, conflicts with people and/or conflicts with the physical environment (Marturano, Trivellato-Ferreira, \& Gardinal, 2009). Squassoni and Matsukura (2014), 
identified in their study that $14.8 \%$ of the participants had a low perception of social support from teachers and $19.2 \%$ with hyperactivity and emotional symptoms also presented relationship and school conduct problems. These characteristics can lead to impairments in learning. In contrast, the support of family, community, friends and teachers can be a protective factor, with repercussions in adult life.

The sum of the conditions of the family environment and the school space, in this teaching-learning process, can contribute to the students' motivation to learn and therefore, to the support perceived by these students (Miller, Das, \& Chakravarthy, 2011). According to Santos, Moraes and Lima (2018), motivation for learning involves the investment of internal resources for the learning process, which is a fundamental aspect for satisfactory school performance.

The study by Zambon and Rose (2012) characterized the motivation of a group of students according to the cognitive aspects, self-image, attributions of causality and achievement goals to identify relationships between these constructs and high, medium and low performance in the Portuguese discipline for $6^{\text {th }}$ and $7^{\text {th }}$ grade EE students. The results highlighted significant differences between students with high, medium and low school performance. Motivational scores for middle and lower performance students were lower, with these also presenting a lower self-image, attributing their performance to external causes and to their ability to learn. They also showed that they used the learning goal less than the higher performance group. Students with higher performance showed greater selfimage in reading and writing with attribution of their results to their ability, dedication and effort employed with greater use of the learning goal, characterizing their intrinsic and extrinsic motivation (Bzuneck, 2009; Miller et al., 2011; Santos et al., 2018).

A study by Paulino, Sá and Silva (2015) investigated the relationship between motivation, learning and school success. The study used the Escala de Autorregulação da Motivação na Aprendizagem (EAMA - Self-Regulation Scale of Motivation in Learning) with 316 students of the $7^{\text {th }}$ and $9^{\text {th }}$ grade. The results indicated that the expectations of self-efficacy, the importance of the task and the achievement goals explained the use of strategies of self-regulation of the motivation in learning. For Paulino et al. (2015), the use of an appropriate motivational strategy implied greater self-knowledge and influenced the orientation towards learning. The authors concluded that the desired goals are achieved, reflecting the interest in the tasks and the functionality of the activity, understanding the competence to accomplish them. They also emphasized the relevance of the student being intentionally involved in the decision of the motivation regulation strategy as a fundamental aspect of the competencies of self-regulation of the learning.

In this sense, in Elementary Education, an adequate environment in all contexts can promote the development of competencies and overcome challenges in relation to social and academic aspects (Marturano et al., 2009). In Brazil, the calculation of school performance is based on systems that aim to evaluate Education as a whole and thereby enable possible quality improvements and universal access. For this, concrete indicators are used for the formulation, reformulation and monitoring of public policies directed toward this area (LDB-EN articles 12, 13 and 24).

In the present study, school performance is understood as measured standards of the assessments of the content learned, which allow schools to position student learning on a numerical scale. The students' progression is related to the fact that they are above or below the average established by the Teaching Unit or education departments of each city or state (Dal'Igna, 2007).

Based on school progression, the aim of this work was to verify whether the School Performance variable can be explained by the Adolescent Social Skills (ASS), Motivation to Learn and Perception of Social Support constructs in groups of students that were either in the regular grade of High School or presented an age/ grade discrepancy in Elementary Education. This study also aimed to compare the constructs in the groups. A greater impact was expected from the Adolescent Social Skills, Perception of Social Support and Motivation to Learn on the school performance of the regular grade students. When comparing the groups, it was expected to identify, as found by Fernandes et al. (2018), that the regular grade students were more skilled, had better social perception, greater motivation to learn and higher final mean scores than the age/grade discrepancy students enrolled in acceleration classes.

\section{Method}

\section{Participants}

Participants of the study were 500 students, with ages varying from 15 to 18 years $(M=16.37 ; S D=0.90)$ 
separated into two groups. Of the total sample, 299 were male (59.8\%) and 201 female (40.2\%). Regarding schooling, 250 were attending Elementary Education and presented an age/grade discrepancy, being enrolled in acceleration classes (first group), the other half were attending High School in the regular grades (second group). Regarding the economic level, in the first group, with age/grade discrepancy, $20(8.0 \%)$ of the students were of economic level A, 45 (18.8) B1, 41 (16.4\%) B2, $68(27.2 \%)$ C1 and $76(30.4 \%)$ were of C2. In the second group, without age/grade discrepancy, there were $24(9.6 \%)$ participants of economic level A, 48 (19.2\%) of $\mathrm{B} 1,57(22.8 \%)$ of $\mathrm{B} 2,69(27.6 \%)$ of $\mathrm{C} 1$ and 52 $(20.8 \%)$ of $\mathrm{C} 2$

\section{Instruments}

Social Skills Inventory for Adolescents - IHSADel-Prette (Z. Del Prette \& Del Prette, 2009). This inventory evaluates the social skills of adolescents based on self-reports regarding everyday situations. It is composed of 38 items that cover different social skills and is divided into six factors: (1) Empathy $(\alpha$ $=.81$ ); (2) Self-control $(\alpha=.77)$; (3) Civility $(\alpha=.81)$; (4) Assertiveness $(\alpha=.71)$; (5) Affective Approach $(\alpha=.61)$; (6) Social resourcefulness $(\alpha=.57)$ and total score $(\alpha=.91)$. The responses are arranged on a five-point Likert-type scale, ranging from 0 (never) to 4 (always).

The Social Support Appraisals (SS-A) Scale Antunes and Fontaine, 1995, adapted for Brazil by Squassoni \& Matsukura, 2014. This is a Likert-type scale, with Cronbach's alpha for a total scale of .74 , in which the questions receive a score between 6 points (Strongly Agree) and 1 point (Strongly Disagree) in the affirmative questions and inverted in the negative questions. In the affirmative questions (23 questions) the score ranges from six to one and in the negative questions ( 7 questions: 4, 11, 18, 22, 28, 29 and $30)$ the score is reversed and varies from one to six. The instrument has four subscales defined as follows: Subscale 1 - Family ( $\alpha=.57$ ). Composed of eight items that assess the degree to which a person feels loved, respected and included by the family. Subscale 2 - Friends $(\alpha=.72)$. Composed of seven items that assess the degree to which a person feels loved, respected and included by friends. Subscale 3 - Teachers $(\alpha=.79)$. Composed of seven items that assess the extent to which a person feels loves, respected and included by teachers. Subscale 4 - Others $(\alpha=.71)$. Composed of eight items that assess the degree to which a person feels loved, respected and included by others in general.

Escala de Motivação para Aprendizagem no Ensino Fundamental Motivation (EMA-EF - Learning Motivation in Elementary Education Scale, Neves \& Boruchovitch, 2007), which assesses how the students direct their efforts to learn. It has internal consistency $(\alpha=.82)$ for the full scale and is divided into a two-factor structure, Intrinsic Motivation (IM) and Extrinsic Motivation (EM) with the following definitions: Factor 1 - Intrinsic Motivation - IM $(\alpha=.87)$. This contains 17 items and signifies the student's interest in the task for the pleasure of doing it. Factor 2 - Extrinsic Motivation - EM $(\alpha=.83)$. This contains 14 items and means that the task is a means to achieve a reward for the performance of the student.

School performance was measured using the means of the students' Annual School Performance scores, obtained from the final reports, together with information from the School Supervisors, Secretaries and Councilors of the educational units where the study was developed.

\section{Ethical procedures}

The present study was submitted to the University's Ethics Committee and approved under Authorization No. 1.550.429 on May 18, 2016. The parents or guardians of the students signed a consent form agreeing to their participation in the study. They were informed of the guarantee of anonymity and the possibility of withdrawing at any time in the interest of the participant. The students also signed a consent form. This document was prepared in language accessible to minors or legally incapacitated people that were able to give their consent and therefore participate in the study, without affecting the consent of their legal guardians.

\section{Data Collection Procedures}

The study was carried out in six State Public Schools. Three of them were located in the municipality of Rio de Janeiro, one in the municipality of Nova Iguaçu and two in the municipality of Niterói in the state of Rio de Janeiro. Of the schools chosen, three of them were High School Education and Technical schools and the others Elementary Education (EE) schools. In order to carry out the study, invitations to participate were made at the parents' meetings that the schools regularly held and in class visits, explaining the aims.

Psico-USF, Bragança Paulista, v. 26, n. 3, p. 533-543, jul./set. 2021 


\section{Data Analysis Procedures}

The collected data were statistically analyzed using the Statistical Package for the Social Sciences for Windows (SPSS, version 22) software. Multiple linear regression analyses were carried out in order to investigate whether the Social Skills of Students, Perception of Social Support and Motivation to Learn explanatory variables explained the School Performance criterion variable. Student's $t$-test was used to compare the variables in the two study groups.

\section{Results}

The results indicated that there was a predictive relationship between the Social Skills of Students, Perception of Social Support, Motivation to Learn explanatory variables and the School Performance criterion variable for groups of students with and without age/grade discrepancy. For the Adolescent Social Skills, the model was significant for the group with discrepancy $\left(F(12,237)=11,974, p<.001, r^{2}=\right.$ $.346)$ and for those in the regular grade $[F(12,237)$ $\left.=16,883, p<.001, r^{2}=.434\right]$. For the Perception of Social Support, the model had a significant impact for the group with discrepancy $(\mathrm{F}(4,245)=4.270, p<.01$, $\left.r^{2}=.05\right)$ and for those in the regular grade $[F(4,245)$ $\left.=9.168, p<.01, r^{2}=0.12\right]$. For Motivation to Learn, the model was significant for the group with discrepancy $\left(F(1,248)=3,895.02, p<.01, r^{2}=.49\right)$ and for those in the regular grade $[F(1,248) 10,635.97 p<.01$, $\left.r^{2}=.78\right]$.

Regarding the analysis of the comparison of means between the groups, Table 1 presents the descriptive values of Adolescent Social Skills, Motivation to Learn and Perception of Social Support $(N=$ 500). Student's $t$-tests were used to assess the extent to which students' social skills scores differed between the groups of students with and without age/grade discrepancy. The results demonstrate that the majority of the variables presented significant differences, except in the Empathy total, in the Self-control difficulty, in the Civility total, F4 Assertiveness frequency, in the Affective Approach frequency and Affective Approach total, in the Development total and in the Scale total. The students in the regular grade present higher means in the Frequency of skillful behaviors in all the factors of the scale and in the totals by factor. In contrast, the students with age/grade discrepancy had greater difficulty in presenting skillful behaviors in all the factors, in the totals by factor and in the general score of the scale.
For the Perception of Social Support the results show that the students from the group in the regular grade presented significantly higher scores in the social support from friends, others and in the total scale. Motivation to Learn was statistically different for the students groups with and without discrepancy in Intrinsic Motivation, Extrinsic Motivation and in the Total of the Motivation to Learn scale. The results demonstrate that the group in the regular grade had significantly higher scores in intrinsic and extrinsic motivation and also in the total score.

\section{Discussion}

The school performance of age/grade discrepancy students had $34.46 \%$ of its variability explained by the Adolescent Social Skills. For students without discrepancy, this percentage was $43.34 \%$. In this construct, it was observed that the age/grade discrepancy students, although enrolled in acceleration classes, required specific attention in the relational aspects with a focus on performance, which can contribute to adjust their progression and to them learning the necessary content to progress in their schooling.

Nunes et al. (2014) highlighted that students with prospects for a better future feel good at school and plan greater possibilities to construct projects with higher expectations of continuity in their studies. When reporting the results of the aspects "feeling good at school" and "I like going to school" with higher means than "trust in colleagues", it was observed that the relationships between peers and education professionals needed to be worked on to construct interactions that can act as protective factors. Accordingly, Pizato et al. (2014) found that there was evidence of moderate stability of externalizing behaviors for children with behavioral problems with less elaborate repertoires of social skills. This data can be seen as a sign of flexibility and vulnerability to environmental influences, which makes it possible for school activities to promote socially skilled behaviors.

The perception of Social Support significantly explained 5\% of the variability in School Performance for the group with discrepancy and $12 \%$ for the regular progression group. Teachers, managers and other collaborators can compose a support network that makes it possible to face the difficulties in order to outline prospects for a better future for students that have already experienced failure of a school grade (Nunes et al., 2014). Within this context, the perception of social 
Table 1.

Differences in the levels of Adolescent Social Skills, Motivation to Learn and Perception of Social Support of students for groups with and without age/grade discrepancies $(N=500)$

\begin{tabular}{|c|c|c|c|c|c|c|}
\hline Variables & Group & $M$ & $S D$ & $t$ & $d f$ & $P$ \\
\hline \multicolumn{7}{|c|}{ Social Skills Inventory for Adolescents - IHSA-Del-Prette } \\
\hline \multirow[t]{2}{*}{ F1_Frequency_Empathy } & With dis. & 26.66 & 7.94 & -2.71 & 498 & $0.01 * *$ \\
\hline & Without dis. & 28.42 & 6.59 & & & \\
\hline \multirow[t]{2}{*}{ F1_Difficulty_Empathy } & With dis. & 11.97 & 9.03 & 4.63 & 498 & $0.00^{* *}$ \\
\hline & Without dis. & 8.8 & 5.98 & & & \\
\hline \multirow[t]{2}{*}{ F1_Total_Empatia } & With dis. & 14.68 & 12.13 & 1.61 & 498 & 0.10 \\
\hline & Without dis. & 19.63 & 6.59 & & & \\
\hline \multirow[t]{2}{*}{ F2_Frequency_Self-control } & With dis. & 15.39 & 6.51 & -4.64 & 498 & $0.00^{* *}$ \\
\hline & Without dis. & 18.05 & 6.29 & & & \\
\hline \multirow[t]{2}{*}{ F2_Difficulty_Self-control } & With dis. & 12.53 & 5.61 & 1.08 & 498 & 0.28 \\
\hline & Without dis. & 11.97 & 6.02 & & & \\
\hline \multirow[t]{2}{*}{ F2_Total_Self-control } & With dis. & 2.86 & 1.37 & -3.33 & 498 & $0.00^{* *}$ \\
\hline & Without dis. & 6.08 & 2.42 & & & \\
\hline \multirow[t]{2}{*}{ F3_Frequency_Civility } & With dis. & 17.08 & 4.94 & -6.36 & 498 & $0.00^{* *}$ \\
\hline & Without dis. & 19.65 & 4.07 & & & \\
\hline \multirow[t]{2}{*}{ F3_Difficulty_Civility } & With dis. & 6.47 & 6.22 & 7.77 & 498 & $0.00 * *$ \\
\hline & Without dis. & 2.94 & 3.57 & & & \\
\hline \multirow[t]{2}{*}{ F3_Total_Civility } & With dis. & 10.6 & 7.34 & 1.77 & 498 & 0.09 \\
\hline & Without dis. & 16.71 & 4.25 & & & \\
\hline \multirow[t]{2}{*}{ F4_Frequency_Assertiveness } & With dis. & 18.54 & 6.55 & -1.25 & 498 & 0.23 \\
\hline & Without dis. & 19.22 & 5.61 & & & \\
\hline \multirow[t]{2}{*}{ F4_Difficulty_Assertiveness } & With dis. & 9.17 & 6.8 & 4.63 & 498 & $0.00^{* *}$ \\
\hline & Without dis. & 6.72 & 4.85 & & & \\
\hline \multirow[t]{2}{*}{ F4_Total_Assertiveness } & With dis. & 9.37 & 8.94 & 2.77 & 498 & $0.00^{* *}$ \\
\hline & Without dis. & 12.5 & 4.66 & & & \\
\hline \multirow[t]{2}{*}{ F5_Frequency_Approach } & With dis. & 13.14 & 4.63 & 1.28 & 498 & 0.20 \\
\hline & Without dis. & 12.59 & 4.96 & & & \\
\hline \multirow[t]{2}{*}{ F5_Difficulty_Approach } & With dis. & 8.12 & 4.62 & -1.93 & 498 & $0.05^{*}$ \\
\hline & Without dis. & 8.93 & 4.77 & & & \\
\hline \multirow[t]{2}{*}{ F5_Total_Approach } & With dis. & 5.02 & 6.56 & -0.54 & 498 & 0.59 \\
\hline & Without dis. & 3.66 & 4.11 & & & \\
\hline \multirow[t]{2}{*}{ F6_Frequency_Development } & With dis. & 10.86 & 5.38 & -2.9 & 498 & $0.01 * *$ \\
\hline & Without dis. & 12.18 & 4.76 & & & \\
\hline \multirow[t]{2}{*}{ F6_Difficulty_Development } & With dis. & 6.83 & 3.87 & 3.76 & 498 & $0.00 * *$ \\
\hline & Without dis. & 5.58 & 3.56 & & & \\
\hline \multirow[t]{2}{*}{ F6_Total_Development } & With dis. & 4.04 & 5.55 & -0.15 & 498 & 0.89 \\
\hline & Without dis. & 6.61 & 4.16 & & & \\
\hline \multirow[t]{2}{*}{ HSA_Frequency_Total } & With dis. & 101.66 & 28.1 & -3.59 & 498 & $0.00^{* *}$ \\
\hline & Without dis. & 110.12 & 24.36 & & & \\
\hline
\end{tabular}


Table 1.

Differences in the levels of Adolescent Social Skills, Motivation to Learn and Perception of Social Support of students for groups with and without age/grade discrepancies ( $N=500)$ (Continuation)

\begin{tabular}{|c|c|c|c|c|c|c|}
\hline Variables & Group & $M$ & $S D$ & $t$ & $d f$ & $P$ \\
\hline \multicolumn{7}{|c|}{ Social Skills Inventory for Adolescents - IHSA-Del-Prette } \\
\hline \multirow[t]{2}{*}{ IHSA_Difficulty_Total } & With dis. & 55.08 & 28.99 & 4.44 & 498 & $0.00 * *$ \\
\hline & Without dis. & 44.93 & 21.63 & & & \\
\hline \multirow[t]{2}{*}{ IHSA_Total } & With dis. & 46.58 & 38.89 & 0.6 & 498 & $0.00 * *$ \\
\hline & Without dis. & 65.19 & 21.78 & & & \\
\hline \multicolumn{7}{|c|}{ Motivation for Learning for Elementary Education Scale - EMA-EF } \\
\hline \multirow[t]{2}{*}{ Intrinsic (IM) } & With dis. & 38.1 & 6.1 & -6.75 & 498 & $0.00^{* *}$ \\
\hline & Without dis. & 41.65 & 5.64 & & & \\
\hline \multirow[t]{2}{*}{ Extrinsic $(\mathrm{EM})$} & With dis. & 30.48 & 5.31 & -7.9 & 498 & $0.00 * *$ \\
\hline & Without dis. & 33.73 & 3.77 & & & \\
\hline \multirow[t]{2}{*}{ Mot_Total (MT) } & With dis. & 68.58 & 8.06 & -9.45 & 498 & $0.00^{* *}$ \\
\hline & Without dis. & 75.38 & 8.02 & & & \\
\hline \multicolumn{7}{|c|}{ Social Support Appraisal scale - SS-A } \\
\hline \multirow[t]{2}{*}{ SS-A_Family } & With dis. & 40.18 & 6.91 & -1.24 & 498 & 0.23 \\
\hline & Without dis. & 40.93 & 6.66 & & & \\
\hline \multirow[t]{2}{*}{ SS-A_Friends } & With dis. & 32.41 & 5.64 & -6.8 & 498 & $0.00^{* *}$ \\
\hline & Without dis. & 35.45 & 4.26 & & & \\
\hline \multirow[t]{2}{*}{ SS-A_Teachers } & With dis. & 28.49 & 4.97 & -1.34 & 498 & 0.19 \\
\hline & Without dis. & 29.17 & 6.32 & & & \\
\hline \multirow[t]{2}{*}{ SS-A_Others } & With dis. & 34.56 & 5.56 & -6.09 & 498 & $0.00 * *$ \\
\hline & Without dis. & 37.58 & 5.53 & & & \\
\hline \multirow[t]{2}{*}{ SS-A_Total } & With dis. & 135.65 & 17.33 & -4.8 & 498 & $0.00^{* *}$ \\
\hline & Without dis. & 143.14 & 17.56 & & & \\
\hline
\end{tabular}

Note: $*-p<.05 ; * *-p<.01$

support can help students to cope with academic and personal problems, since a healthy structure can help them to present functional behaviors in face of the difficulties encountered (Bokhorst et al., 2010; Dias \& Leite, 2014; Feitosa \& Del Prette, 2005). In addition, the results indicated that students without age/grade discrepancy presented less risk factors than those with this discrepancy.

Motivation to Learn explained $49 \%$ of the performance of the students with an age/grade discrepancy and $78 \%$ of the performance of those in the regular grade. The acceleration classes present a differentiated pedagogical proposal aiming to revive the students' commitment to their learning process. It is understood that discrepancy students enrolled in acceleration classes may have broadened the skills repertoire and are consequently motivated to achieve better school performance (Elias \& Marturano, 2014; Zambon \& Rose, 2012), although the impact is less than in students in the regular grade.

The Motivation to Learn presented, in the total of the scale, a greater impact on the School Performance of the students with regular progression than on that of the discrepancy group. Zambon and Rose (2012) observed that the cognitive aspects of motivation can provide indicators of the quality of this construct and proposed an investigation of both the cognitive and contextual aspects of motivation in the school environment. The results found indicate that in addition to cognitive ability, factors that concern the social skills 
of students, the perception of social support and their motivation are also important for the teaching and learning process. Based on the highlighted observations and notes, it is possible to propose a more attentive view of relational issues, without abandoning the content at all stages of Elementary Education. Maintaining the content is justified by the fact that it is required in the selection processes for Technical High School, for entering university and even for jobs.

In the comparison between the groups, the students in the regular grade presented higher means in the Frequencies of behaviors with Empathy, Self-control, Civility, Assertiveness, Social resourcefulness and in the general total of the scale with lower means in Difficulties to behave with Empathy, Self-control, Civility, Assertiveness, Social resourcefulness and in the total of the scale than the age/grade discrepancy students. Fernandes et al. (2018) found that satisfactory school performance can be explained by empathetic behavior, with civility, self-control and with sufficient social resourcefulness to establish healthy social relationships and act as a protective factor, corroborating the studies of Z. Del Prette \& Del Prette (2009) and Wyler and Schueda (2014). These studies indicate that, although the Acceleration of studies possibly contributes to the development of some social skills, a less elaborated repertoire may partly explain the condition of successive failures experienced by this group.

The Perception of Social Support of the students without age/grade discrepancy presented significantly higher scores in the subscales Friends, Others and in the total Perception of Support. Squassoni and Matsukura (2014) identified a relationship between the perception of social support and the socio-emotional development of children and adolescents, of which, even when faced with differences, the teacher can be an important agent. However, at this stage the perception of support from friends is greater.

In the comparison between the groups, the Motivation to Learn of the students in the regular grade presented a higher mean in Intrinsic and Extrinsic Motivation and in the total of the scale. Students' motivation for learning and internalizing the need for disciplined behaviors contributed to school performance. These results are in line with the study by Paulino et al. (2015), who indicated that the orientation for the learning of these students can define their engagement in activities. Learning goals reflect how interesting tasks become due to their role in producing knowledge. This intentional decision to get involved in activities can regulate the orientation of motivation and be a guiding aspect of the competences to carry out the activities (Paulino et al., 2015).

\section{Final Considerations}

The aim of this work was to verify whether the School Performance variable can be explained by the Adolescent Social Skills (ASS), Motivation to Learn and Perception of Social Support constructs in groups of students that were in the regular grade of High School and those with an age/grade discrepancy in Elementary Education. This study also aimed to compare the constructs in the groups. The results showed that Social Skills (resources of the student), Perception of Social Support (resources in the school context) and Motivation to Learn positively impact school performance of students, which can help them throughout their school trajectory, mainly in moments of transition, such as at the end of Elementary Education. This study identified variables, existing in the acceleration proposal, which can be exploited to assist in correcting the progression and assisting the continuity of schooling of students that need this readjustment. For this, the individual commitment of all involved is a fundamental condition. If differentiated activities are applied after experiences of grade failure, it can be inferred that a view focused on the variables highlighted can reduce the negative impact for students that have difficulties in the process.

The present work also aimed to evaluate in students in the age/grade correction program, how their ASS, Perception of Social Support and Motivation to Learn were presented in an environment with conditions proposed for this profile of students. The feedback of these data can also contribute to the reassessment of the methods used in the context of the acceleration of studies program, considering the personal resources of the students in a situation of age/ grade discrepancy.

The present study presents some limitations as it was carried out in a period interrupted by strikes, which may have influenced the students' interest in the proposed contents, since the school routine was changed. For the participants in the regular grades, a portion of the sample was attending technical vocational training and students with age/grade discrepancies enrolled in regular classes were not investigated. Further studies with students regularly enrolled in high school are recommended. Another aspect is that the data collection only occurred with students from public education 
institutions, considering that the behavior of the variables could also be compared among students from private institutions. A prospective and longitudinal study is suggested with the aim of monitoring the development of Adolescent Social Skills, Perception of Social Support and Motivation to Learn during the grade progression correction process and in the transition to High School Education. Studies that contemplate the perception of parents and teachers about the behavior of their children/students considering the impact of the variables proposed in the model of the present study on school performance, would greatly contribute to the partnership between family and school. Programs with preventive actions (such as monitoring or tutoring for students with an age/grade discrepancy and parental guidance in the homework) could be created so that, throughout Elementary Education, they present results in the interactions within the school environment, with the aim of improving the individual resources of students, developing activities to be implemented in the family nucleus, by teachers and other existing employees in the teaching and learning process and contributing to good performance. The data presented here can serve as a contextual view of the participating institutions and should be generalized with caution.

\section{References}

Angelin, A. P. (2012). Promovendo babilidades sociais na educação básica: Uma proposta de intervenção. Recuperado de https://www.lume.ufrgs.br/handle/10183/49115

Antunes, C., \& Fontaine, A. M. (2005). Percepção de Apoio Social na adolescência: análise fatorial confirmatória da escala Social Support Appraisals. Paidéia 15(32), 355-366. doi: 10.1590/ S0103-863X2005000300005.

Barreto, S. de O., Freitas, L. C., \& Del Prette, Z. (2011). Habilidades sociais na comorbidade entre dificuldades de aprendizagem e problemas de comportamento: uma avaliação multimodal. Psico, 42(4), 503-510.

Bokhorst, C. L., Sumter, S. R., \& Westenberg, P. M. (2010). Social Support from Parents, Friends, Classmates, and Teachers in Children and Adolescents Aged 9 to 18 Years: Who Is Perceived as Most Supportive? Social Development, 19(2), 417426. doi: 10.1111/j.1467-9507.2009.00540.x
Brasil. Ministério da Educação, Lei no 9.394, de 20 de dezembro de 1996 (2014). Plano Nacional de Educação (PNE). Brasília: Centro de Documentação e Informação Coordenação Edições Câmara.

Bzuneck, J.A. (2009). A motivação do aluno: aspectos introdutórios. In: Boruchovtch, E.; Bzuneck, J.A. (Orgs.), A Motivação do Aluno (pp. 9-36). Rio de Janeiro: Vozes.

Casali-Robalinho, I. G., Del Prette, Z. A. P., \& Del Prette, A. (2015). Habilidades sociais como preditoras de problemas de comportamento em escolares. Psicologia: Teoria e Pesquisa, 31, 321-330.

Dal'Igna, M. C. (2007). Desempenho escolar de meninos e meninas: há diferença? Educação Em Revista, 46, 241-267. doi: 10.1590/S0102-46982007000200010

Dascanio, D., Del Prette, A., Barham, E. J., Rodrigues, O. M. P. R., Fontaine, A. M. G. V., \& Del Prette, Z. A. P. (2015). Habilidades Sociais, Competência Acadêmica e Problemas de Comportamento em Crianças com Diferentes Níveis de Plumbemia. Psicologia:Reflexão e Crítica, 28(1), 166-176.

Del Prette, A., \& Del Prette, Z. A. P. (2009). Inventário de habilidades sociais para adolescentes. São Paulo: Casa do Psicólogo.

Dias, T. L., \& Leite, L. L.G. (2014). Rede de apoio social e afetivo e estratégias de enfrentamento na doença falciforme: um olhar sobre a pessoa e a família. Psicologia em Revista, 20(2), 353-373. doi: 10.5752/P.1678-9523.2014v20n2p353

Elias, L. C. dos S., \& Marturano, E. M. (2014). “ Eu Posso Resolver Problemas "e Oficinas de Linguagem: Intervenções para a Queixa Escolar. Psicologia: Teoria e Pesquisa, 30(1), 35-44.

Feitosa, F. B., \& Del Prette, Z. A. P. (2005). Suporte social, nível socioeconômico e o ajustamento social e escolar de adolescentes portugueses. Temas em Psicologia, 13(2), 129-138.

Fernandes, L. M., Leme, V. B. R., Elias, L. C. S., \& Soares, A. B. (2018). Preditores do desempenho escolar ao final do ensino fundamental: histórico de reprovação, habilidades sociais e apoio social. Temas em Psicologia, 26(1), 215-228. doi: 10.9788/ tp2018.1-09pt

Instituto Nacional de Estudos e Pesquisas Educacionais Anísio Teixeira (2017). Censo Escolar. Accessed 
on 10 April, 2019, at http://portal.inep.gov.br/ educacao-basica

Marturano, E. M., Trivellato-Ferreira, M. de C., \& Gardinal, E. C. (2009). Estresse cotidiano na transição da $1^{a}$ série: percepção dos alunos e associação com desempenho e ajustamento. Psicologia: Reflexão e Crítica, 22(1), 93-101. https://doi.org/10.1590/ S0102-79722009000100013

Miller, J. G., Das, R., \& Chakravarthy, S. (2011). Culture and the role of choice in agency. Journal of Personality and Social Psychology, 101(1), 46-61. https://doi. org $/ 10.1037 /$ a0023330

Neves, E. R. C., \& Boruchovitch, E. (2007). Escala de avaliação da motivação para aprender de alunos do ensino fundamental (EMA). Psicologia: Reflexão e Crítica, 20(3), 406-413. doi: 10.1590/ S0102-79722007000300008

Nunes, T. G. R., Pontes, F. A. R., Silva, L. I. C., \& Dell'Aglio, D. D. (2014). Fatores de risco e proteção na escola: Reprovação e expectativas de futuro de jovens paraenses. Psicologia Escolar e Educacional, 18(2), 203-210. doi: 10.1590/2175-3539/2014/0182732

Paulino, P., Sá, I., \& Silva, A. L. (2016). Crenças e estratégias da motivação na aprendizagem: Desenvolvimento de uma escala. Psychologica, 58(1), 65-87.

Perassinoto, M.G.M., Boruchovitch, E., \& Bzuneck, J.A. (2013). Estratégias de aprendizagem e motivação para aprender de alunos do Ensino Fundamental. Avaliação Psicológica, 12(3), 351359.

Pereira, M. T., Marturano, E. M., Gardinal-Pizato, E. C., \& Fontaine, A. M. G. (2011). Possíveis contribuições da educação infantil para o desempenho e a competência social de escolares. Psicologia Escolar e Educacional (Impresso), 15(1), 101-109. doi: 10.1590/S1413-85572011000100011
Pizato, E. C. G., Marturano, E. M., \& Fontaine, A. M. G. V. (2014). Trajetórias de habilidades sociais e problemas de comportamento no ensino fundamental: influência da educação infantil. Psicologia: Reflexão e Crítica, 27(1), 189-197.

Santos, A. A. A., Moraes, M. S., \& Lima, T. H. (2018). Compreensão de leitura e motivação para aprendizagem de alunos do ensino fundamental. Psicologia Escolar e Educacional,22(1), 93-101. doi: 10.1590/2175-35392018012208

Sapienza, G., Schoen, T., \& Fisberg, M. (2014). Efeitos da interveção psicológica na competência social de adolescentes obesos. Psicologia, Saúde e Doenças, 15(3), 612-622.

Silva, S. B. da, \& Rapoport, A. (2015). Desempenho escolar de crianças em situação de vulnerabilidade social. Revista Educaşão Em Rede: Formação e Prática Docente, 5, 1-26.

Squassoni, C. E., \& Matsukura, T. S. (2014). Adaptação transcultural da versão portuguesa do social support appraisals para o Brasil. Psicologia: Reflexão e Crítica, 27(1), 71-80. doi: 10.1590/ S0102-79722014000100009

Wyler, M. M., \& Schueda Raiser, J. (2014). Habilidades Sociais e Educação: avanços e possibilidades. Agora, 19(2), 40-63.

Zambon, M. P., \& Rose, T. M. S. De. (2012). Motivação de alunos do ensino fundamental: relações entre rendimento acadêmico, autoconceito, atribuições de causalidade e metas de realização. Educaşão e Pesquisa, 38(4), 965-980. doi: 10.1590/ S1517-97022012000400012

Recebido em: 01/08/2019

Reformulado em: 11/05/2020 Aprovado em: 17/08/2020 
About the authors:

Humberto Claudio Passeri Medeiros - MSc in Psychology from the Universidade Salgado de Oliveira (UNIVERSO) and a degree in Business Administration from the same university. Pedagogical Coordinator and Teacher in the FAETEC - Fundação de Apoio à Escola Técnica of the state of Rio de Janeiro.

ORCID: https://orcid.org/0000-0002-1091-8136

E-mail: hcpasseri@gmail.com

Adriana Benevides Soares - Clinical Psychologist (UFRJ). Specialist in Cognitive Behavioral Therapy (UniRedentor). MSc and PhD in Psychology from the University of Paris XI. Post-Doctorate (UFSCar). Full Professor of the UERJ Graduate Program. Full Professor of the UNIVERSO Graduate Program. CNPq Productivity Scholarship and Scientist of Nosso Estado by FAPERJ.

ORCID: https://orcid.org/0000-0001-8057-6824

E-mail: adribenevides@gmail.com

Marcia Cristina Monteiro - PhD in Social Psychology, Post-Doctorate in Social Psychology from UNIVERSO. MSc in Social and Personality Psychology from UFRJ. Psychologist and Pedagogue. Specialist in Educational and School Psychology (CFP) and Clinical Psychology (UERJ). Educational advisor at the Fundação de Apoio à Escola Técnica of the State of Rio de Janeiro and teacher at the Universidade Brasil - UNIESP Group.

ORCID: https://orcid.org/0000-0003-3455-2690

E-mail:marcialauriapsi@outlook.com

Contact:

Adriana Benevides Soares

Rua Marechal Deodoro, 211

Niterói-RJ, Brasil

CEP: 24030-060 
